\title{
OPTIMIZATION OF UTILIZATION OF CALF RENNET AND ADULT BOVINE RENNET MIXTURES IN DOMIATI CHEESE MAKING
}

\author{
El-Hawary, M. Y. ; M. A. Salam ; Samar I. Aly ; Dina A. Amer \\ Food scince and technology Department, Faculty of Agriculture , Tanta \\ University
}

\begin{abstract}
Calf rennet has been used in Domiati cheese making for long times. Calf rennet is traditionally obtained from slaughtered calves. However, due to shortage of meat, calves were recommended to be fattened for two years. This cause a sharp decrease of calf rennet available. Researches have been trying to evaluate the applicability of calf rennet substitutes. These substitutes are : adult bovine rennet $(\mathrm{ABR})$, microbial rennet from Mucor miehei (MR) and mixtures of calf rennet and adult bovine rennet at different ratio .

This study was intended to evaluate different close of rennet as alternative to Calf rennet in coagulant milk and factors affecting the enzymes activity.

Results showed that milk clotting time was positive correlated with sodium chloride concentration. But milk clotting time was inversely correlated with calcium chloride concentration and temperature. Milk clotting time was decreased as milk solids increased up to $12 \%$ under all treatments.
\end{abstract}

\section{INTRODUCTION}

Rennet is an extract from the fourth stomach (abomasum or rennetbag) of ruminant animals, principally calves and adult cattle, with the capability of clotting milk by enzymic action. The enzymes extracted from abomasums are menially chymosin (E C. 3.4.4.3) and pepsin (E C. 3.4.4.1) and these are produced in glandular cells in the mucosa. Rennin is the colloquial name given to the enzyme extracted from stomach that coagulates milk.

Because of the limited availability of proper stomachs for rennet production and the large economic losses resulting from the slaughter of young calves, cheese makers have looked for other ways to coagulate the milk.

\section{MATERIALS AND METHODS}

\section{Materials}

\section{Reconstituted skim milk}

Low heat skim milk powder (California- DAIRIES IMC, America) used in this study was a gift from El-Mansoura Company, Egypt. The gross chemical composition of milk was $3.8 \%$ moisture, $33.4 \%$ protein and $0.8 \%$ fat.

\section{Calcium chloride $\left(\mathrm{CaCl}_{2}\right)$}

Pure high grade $\mathrm{CaCl}_{2}$ was obtained from El-Nasr Company for Chemicals, Alexandria, Egypt.

Sodium chloride ( $\mathrm{NaCl})$

Pure food grade $\mathrm{NaCl}$ was obtained from Bairout Company, ElAssafra, El- Dakahlia, Egypt. 


\section{El-Hawary, M. Y. et al.}

\section{Fresh stomachs}

Fresh stomachs of calf and adult bovine abomasua were purchased from the local market (slaughterhouse) in Tanta city, Egypt. The stomachs were used immediately or stored under refrigeration until use.

\section{Methods}

Traditional method for liquid rennet extraction according to Fahmi\& Amer (1962). Preparation of rennet substitutes.

\section{Milk clotting Enzymes used throughout the study}

The rennet and rennet substitutes used in the study was as the fellows:

1) Calf rennet $(\mathrm{CR})$ prepared from young bovine abomasua.

2) Adult bovine rennet (ABR) prepared from adult bovine stomachs.

3) Rennet substitutes as mixtures from (CR) and (ABR) at ratios of (1:1), (1:3) and (3:1) respectively.

Determination of milk clotting time (MCT)

Preparation of milk for measuring MCT was carried according to Fahmi \& Amer (1962).

\section{Calculation of Rennin units}

The number of rennin units (RU) was calculated using the clotting time in seconds following the equation given by Fahmi and Amer (1962). RU/ml or gram $=\mathrm{D} / \mathrm{T} \times 100$. Where:

$\mathbf{R U} / \mathrm{ml}$ or gram $=$ Rennin units $/ \mathrm{ml}$ liquid rennet or gram powder rennet.

$\mathbf{D}=$ Dilution of rennet before its addition to the milk.

$\mathbf{T}=$ Clotting time of $25 \mathrm{ml}$ of standard milk in seconds. The amount of rennet which clotted $25 \mathrm{ml}$ of standard milk in 100 seconds was defined as one rennin unit

Factors affecting enzyme activity

Enzyme activity was expressed as milk clotting time in seconds.

\section{Effect of added concentrations of $\mathrm{CaCl}_{2}$}

A standard suspension of skim milk (12\%, T.S) for the enzyme assay was prepared by adding concentrations of $0.00,0.01,0.02,0.03,0.04$ and $0.1 \%$ of $\mathrm{CaCl}_{2}$. Then $1 \mathrm{ml}$ from rennet and rennet substitutes was added separately to the prepared suspensions and kept at $40{ }^{\circ} \mathrm{C}$. The enzymes clotting activity was determined in seconds.

\section{Effect of temperature}

The effect of temperature on the clotting activity of the enzyme was determined by heating standard skim milk (12\%T.S) containing $0.01 \% \mathrm{CaCl}_{2}$ to temperatures ranged from $30^{\circ}$ to $50{ }^{\circ} \mathrm{C}$. Then $1 \mathrm{ml}$ from rennet or rennet substitutes were added separately and the enzymes clotting activity was determined in seconds.

\section{Effect of substrate concentration}

Various amount of dry skim milk were dispersed in distilled water containing $0.01 \% \mathrm{CaCl}_{2}$ to obtain different concentration of substrate 6,10 , 12,14 , and $16 \%$. Then the enzymes clotting activity was determined in seconds.

\section{Effect of sodium chloride concentrations in milk}

Sodium chloride $(\mathrm{NaCl})$ was added to reconstituted skim milk $(12 \%$ T.S) in gradual concentrations (1\% intervals) from 0 to $4 \%(\mathrm{w} / \mathrm{v})$ and kept at 
$40 \stackrel{\circ}{\circ}$. $1 \mathrm{ml}$ from rennet or rennet substitutes were added separately. Then the enzymes clotting activity was determined in seconds.

\section{RESULTS AND DISCUSSION}

Determination of enzymes optimum conditions for its milk clotting activity (expressed as milk clotting time)

In this part, the optimum conditions of the enzymes for its milk clotting activity were studied. The rennet and rennet substitutes used in the study was as the fellows:-

1- Calf rennet (CR): prepared from young bovine stomachs.

2- Adult bovine rennet (ABR): prepared from adult bovine stomachs.

3- Mixtures of $(C R)$ and (ABR): with the ratio of (1:1), (1:3) and (3:1) respectively.

\section{Effect of different concentration of $\mathrm{CaCl}_{2}$ on MCT}

It well known that kappa casein is not calcium-precipitable as the caseins are secreted, they self-associate into aggregates called micelles in which the alpha and beta caseins are kept from precipitating by their interactions with kappa casein. In essence, kappa casein normally keeps the majority of milk protein soluble and prevents it from spontaneously coagulating (Bowen, 1996). Data in Figure (1) shows the effect of $\mathrm{CaCl}_{2}$ on milk clotting time (MCT). It is clear that increasing the concentration of $\mathrm{CaCl}_{2}$ (at the range of $0.01-0.1 \%$ ) led to decrease milk clotting time in all treatments. In addition, these results revealed that ABR had the highest milk clotting time comparing with $\mathrm{CR}$ or the other rennet substitutes. This may be due to the unsuitable $\mathrm{pH}$ for pepsin activity. Treatments where ABR was added followed the same trend. These results are in agreement with Johnston et al., (2007) who found that Pepsin is most active in acidic environments and its primary site of synthesis and activity is the stomach $\mathrm{pH}$ 1.5 to 2). Pepsin exhibits maximal activity at $\mathrm{pH} 2.0$ and is inactive at $\mathrm{pH} 6.5$ and above however, pepsin is not fully denatured or irreversibly inactivated until pH 8.0.

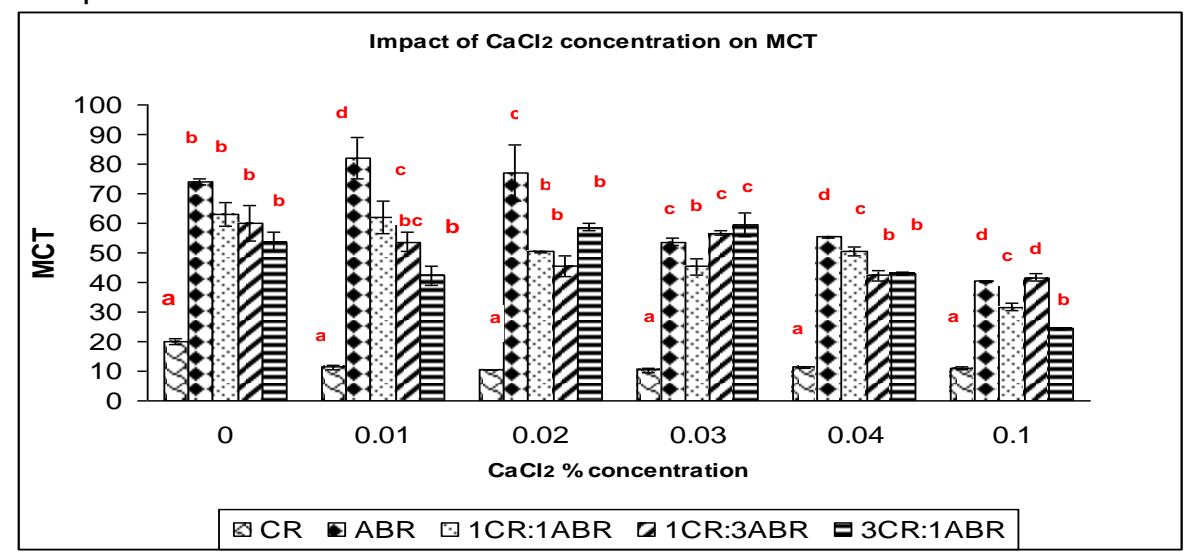

Figure (1): Impact of $\mathrm{CaCl}_{2}$ concentration on MCT of rennet and rennet substitutes (seconds). 


\section{El-Hawary, M. Y. et al.}

\section{Effect of temperature on MCT}

Data in Figure (2) show the effect of temperature on milk clotting time for $\mathrm{CR}$ and its substitutes. These results indicated that milk clotted was faster at high temperature up to $50^{\circ} \mathrm{C}$. The optimum milk clotting time was observed at $40{ }^{\circ} \mathrm{C}$ in all treatments. Could be attributed to this temperature is the optimum to the activity of both rennin and pepsin. These results in agreement with Johnston et al., (2007) who found that Pepsin is most active between $37^{\circ} \mathrm{C}$ and $42^{\circ} \mathrm{C}$. Also these results are in accordance with Tavares (1982) who found that optimum temperature for milk clotting activity of ABR was $42{ }^{\circ} \mathrm{C}$.

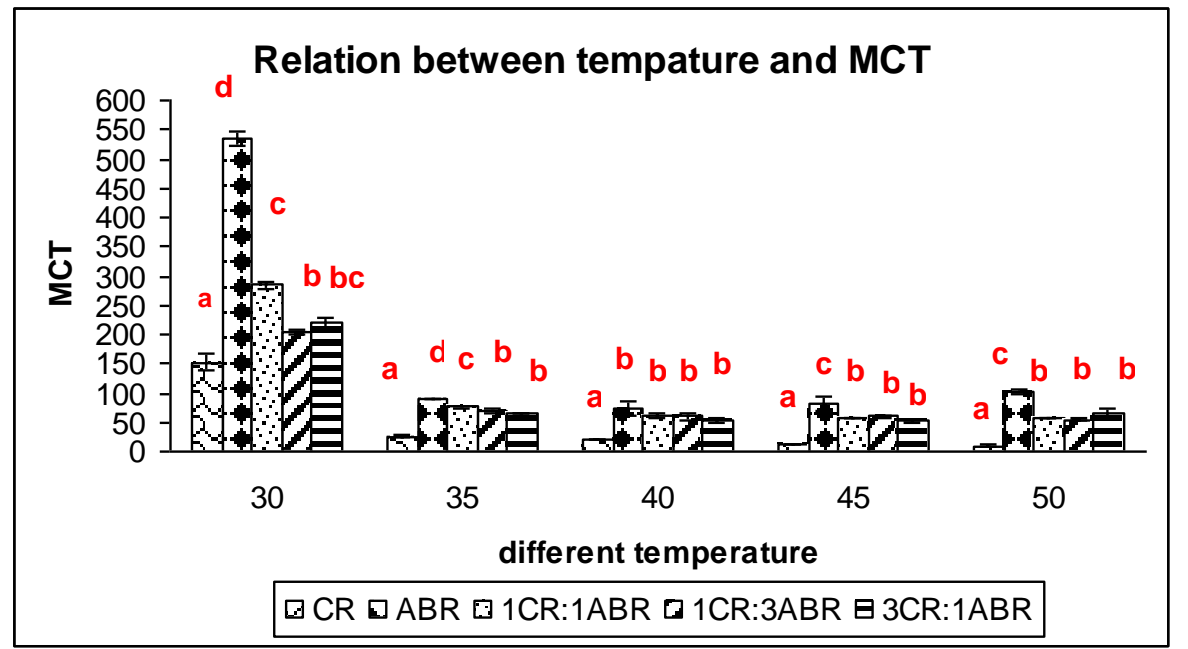

Figure (2): Relation between temperature and milk clotting time (seconds)

\section{Effect of sodium chloride on MCT}

Data given in Figure (3) show the effect of $\mathrm{NaCl}$ on the milk clotting time for $\mathrm{CR}$ and its substitutes. These results revealed that there was a direct positive relationship between the amount of salt added and milk clotting time with $\mathrm{CR}, \mathrm{ABR}$ and their mixtures. These results in agreement with Abd El Salam et al., (1993), who attributed its phenomenon to: The exchange of colloidal calcium for sodium in milk. Disaggregation and dispersion of the colloidal phase of milk. The interaction between sodium chloride with milk and cheese protein. Solubilization of the paracaseinate- phosphate complex. The results clearly indicate that CR has started the coagulation faster than rennet substitutes in both salted and unsalted standard skim milk. 


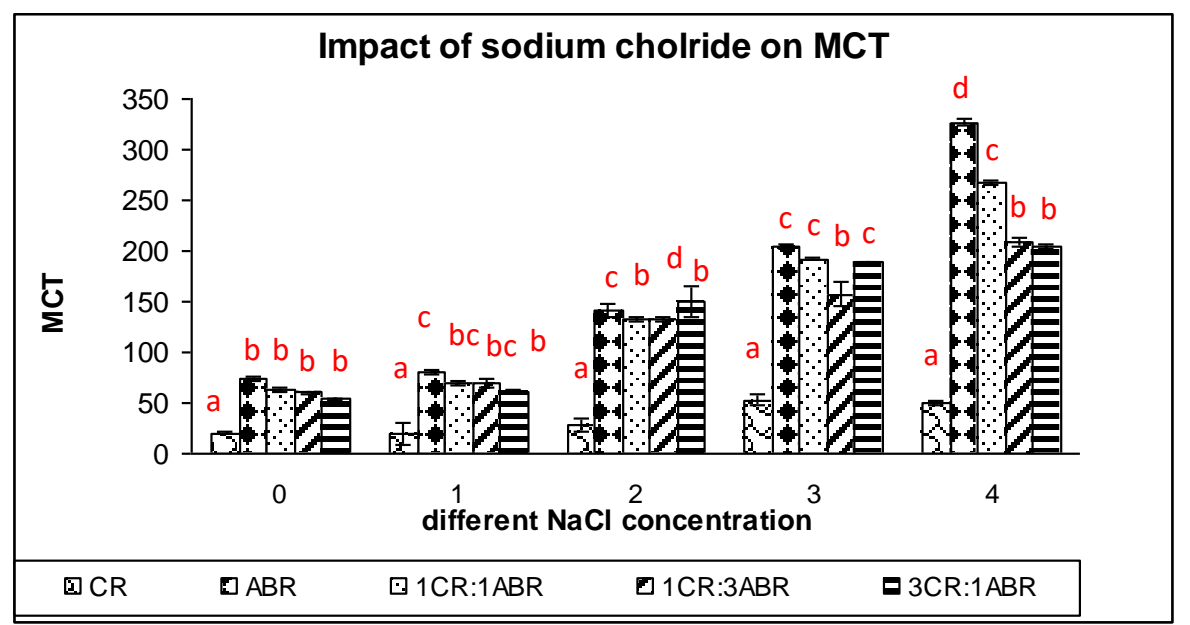

Figure (3): Effect of different $\mathrm{NaCl}$ concentration on milk clotting time by (seconds)

\section{Effect of substrate concentration on MCT}

Data in Figure (4) show the effect of substrate concentration on milk clotting time of $\mathrm{CR}$ and its substitutes. It is clear that the optimum total solid (T.S) for milk clotting time was $12 \%$ with all investigation enzymes.

In addition, these results revealed that ABR was less influence by the changes in substrate concentration. These results are in accordance with results of Baker (1996), who found that the increase in the total solids content of milk led to increase in clotting time with all investigated enzymes. According to the same author the increase in the substrate concentration would increase the vesocity of the primary phase of milk coagulation.

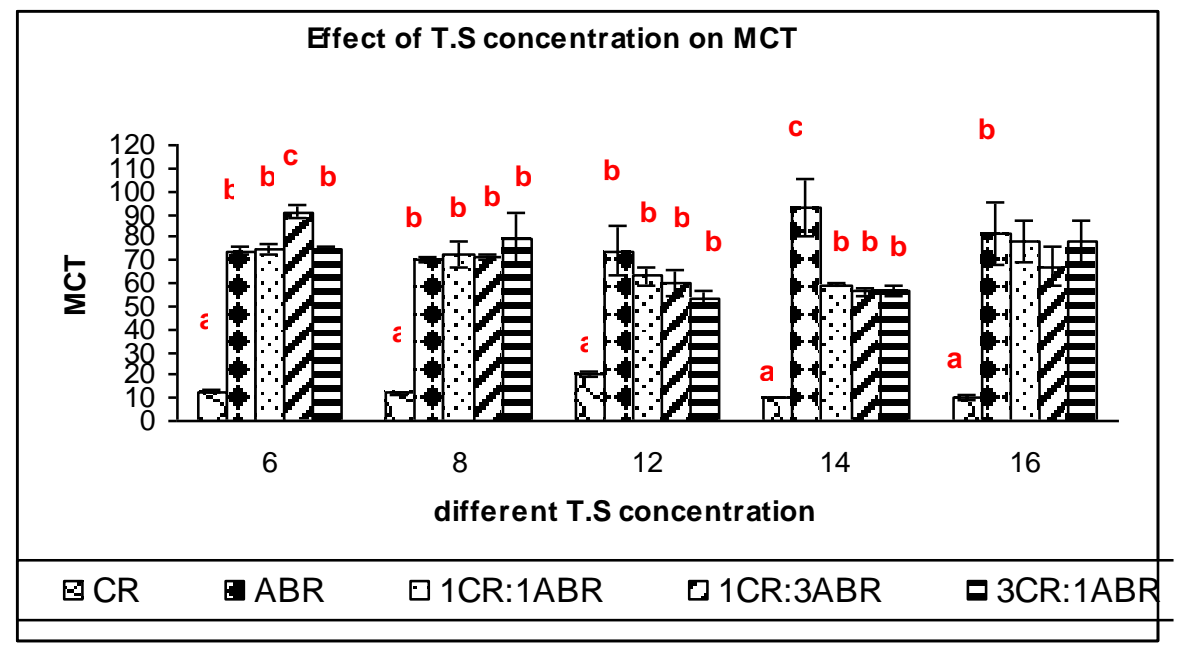

Figure (4): Effect of substrate concentration (as T.S \%) on milk clotting time 


\section{CONCLUSION}

Results obtained in this study showed that the utilization of rennet substitutes as microbial rennet or adult bovine rennet in combination with calf rennet in cheese manufacture provide many advantages including: Protection of the Egyptian livestock by decrease more calves from being slaughter early, use $A B R$ and its combination with $C R$ in cheese manufacture, which easily to find as it considered as animal waste. So were commended the ratios: $1 \mathrm{CR}: 1 \mathrm{ABR}$ as a rennet substitutes.

\section{REFERENCES}

Abd-EI-Salam, M.H. ;Alichandis, E. ;Zerfiridis, G. K. (1993). Domiati and Feta type cheeses Chapter 11 from book Cheese: Chemistry, physics and microbiology: major cheese groups. 301-336.

Baker, A.S. (1996). Studies on milk clotting enzyme from animals sources. M.Sc thesis, Fac. Agric. Kefir El-Sheikh Tanta univ.

Bowen, R. (1996). Chymosin (Rennin) and the Coagulation of Milk. http://www. vivo.colostate.edu/hbooks/pathphys/digestion/stomach/renn in.html

Fahmi, A.H. and Amer, S.N. (1962). A study on the preparation of liquid rennet extract. Megallet El-Eloom El-Zeraeie, Cairo. Univ. 15.

Johnston, N. ;Dettmar, PW ;Bishwokarma, B. ;Lively, MO. ;Koufman, JA. (2007). Activity/stability of human pepsin: implications for reflux attributed laryngeal disease. Laryngoscope 117: 1036-9

Tavers, J.F.da.P.(1982). Production and characterization of enzymes from animal waste material .Dissertation Abstracts International B Sci. and Engineering. 43:1832. 
الظروف المثلى لاستخدام مخاليط منـافح العجول الرضيعة ومنـافح الأبقارفي

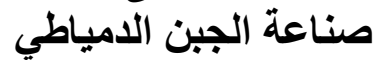

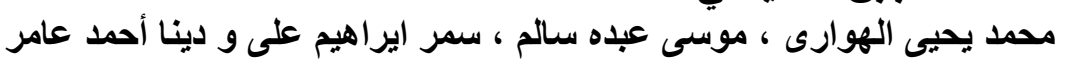

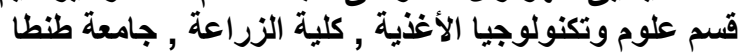

تعتمد صناعة شبيه الجبن الدمياطي على استخدام منفحة العجول. وقد شهدت

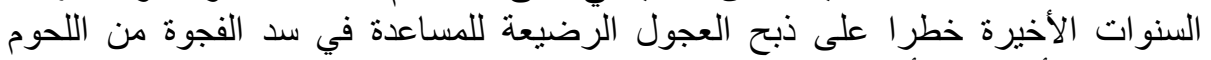

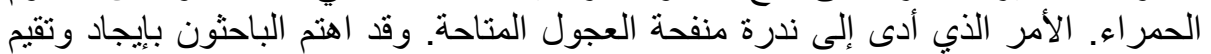

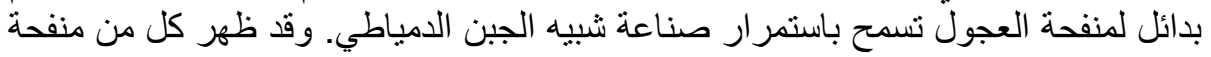

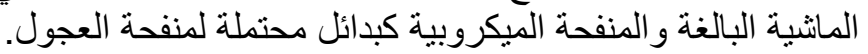

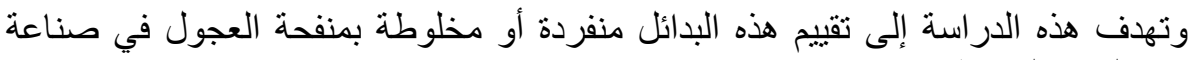

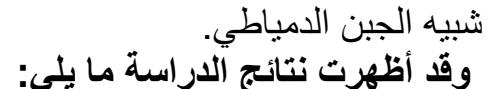

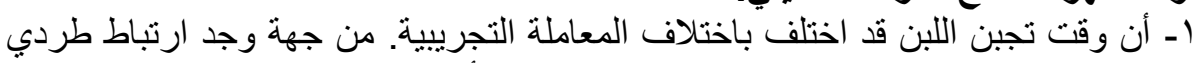

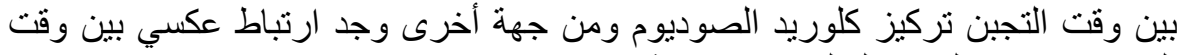

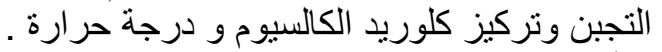

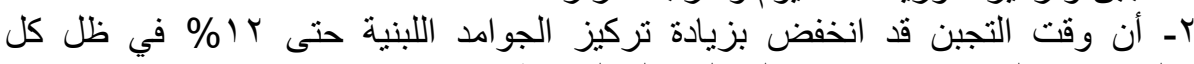
المعاملات التجريبية بالإضافة إلى المعاملة الضابطة.

كلية الزراعة - جامعة المنصورة كلية الزراعة - جامعة طنطا

\author{
قام بتحكيم البحث

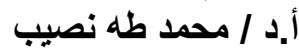 \\ أ.د / محمد / محمد طهي نصي الهوارى
}

